\title{
CHRONIC HEPATITIS C-INFECTED PATIENTS;
}

Assessment of relationship between serum alanine aminotranferase levels and liver histology.

Dr. Javed Ahmed Phulpoto

ABSTRACT... Background: In our region the sensitivity of serum alanine aminotransferase (ALT) levels in predicting the severity of hepatitis C virus (HCV) infection is unclear. Objective: To compare histologic scoring of liver pathology in patients with chronic HCV infection with normal or elevated serum ALT. Study Design: Prospective observational study. Place \& Duration of Study: Liver clinic, Ghulam Mohammad Mahar Medical College Hospital, Sukkur, between January 2010 and December 2010. Methods: Liver biopsies were performed in patients with HCV infection and either normal $(n=40)$ or elevated $(n=76)$ serum ALT levels, and scored for activity and fibrosis using the modified histological activity index. Results: Patients with normal ALT and elevated ALT had similar demographic features. Median (range) histological activity grade was higher in patients with elevated ALT than in those with normal ALT (6 [1-15] vs. 5 $[0-11]$, respectively; $p=0.001$ ), as was the fibrosis stage (2 [0-6] vs. $1[0-6] ; p=0.02$ ). Two patients with normal ALT and 4 with elevated ALT had liver cirrhosis. Conclusions: Among patients with chronic HCV infection, liver lesions are milder in those with normal serum ALT levels than those with abnormal ALT levels. However, some patients with normal ALT too may have advanced liver disease.

Key words: HCV Infection, ALT, Liver Histology

\section{Article Citation}

$\checkmark \quad$ Phulpoto JA. To assess the relationship between serum alanine aminotranferase levels and liver histology in chronic hepatitis C-infected patients, attending liver clinic, Ghulam Mohammad Mahar Medical College Hospital, Sukkur. Professional Med J Feb 2013;20(1):068-071.

\section{INTRODUCTION}

$\mathrm{HCV}$ is a tremendous health problem not only in Pakistan but also worldwide. The world health organization estimates that approximately $3 \%$ of the world population have been infected with HCV thus far. There are about 170 million patients with HCV in the world, and three to four million individuals are diagnosed as new cases every year ${ }^{1,2}$. An approximately 10 million are in Pakistan ${ }^{3,4}$. Among patients with chronic infection, $5 \%-20 \%$ have been reported to develop cirrhosis over 20-25 years ${ }^{5}$. The efficacy of elevation of serum alanine aminotransferase (ALT) levels in prediction of severity of liver injury in patients with chronic hepatitis $C$ is debated ${ }^{6}$. Up to $20 \%$ of patients with infection have persistently normal serum ALT levels. Since ALT levels in these patients may fluctuate, the label 'persistently normal ALT level' is a function of duration of follow up and frequency of ALT determinations ${ }^{7}$. Also, factors such as age, gender and body mass index may influence serum ALT levels in patients with chronic hepatitis $\mathrm{C}^{8}$. The histopathology in hepatitis C virus infection encompasses the entire spectrum of liver damage ranging from acute fulminant hepatic failure to chronic hepatic failure to chronic hepatitis cirrhosis and hepatocellular carcinoma. There are two patterns of chronic hepatitis $C$, hepatitis $C$ with elevated serum ALT and chronic hepatitis $\mathrm{C}$ with normal serum ALT ${ }^{9,10}$.

To study this issue, we compared inflammatory activity and fibrosis on liver histology in patients with normal and elevated serum ALT levels.

\section{METHODS}

In this Prospective study, 116 patients with detectable serum anti-HCV (ELISA) and HCV RNA by PCR, but no history of antiviral (anti-HCV) therapy, were studied at Liver clinic at Ghulam Mohammad Mahar Medical College Hospital, Sukkur, between January 2010 and December 2010. None of the subjects had history of alcohol consumption, thalassemia major, other liver diseases, clinically identified cirrhosis, contraindication for liver biopsy, or positive results for anti-HAV IgM, anti-HBc, HBsAg or anti-HIV antibody. 
During the study period six patients, who came with only one abnormal ALT value, were not included.

Of the 116 patients, 40 had normal serum ALT levels (<49 IU/L; our laboratory cut-off) on at least three consecutive determinations during the previous six months (persistently normal ALT group), whereas 76 had one abnormally high serum ALT determination at least once during the previous one month and on at least one other occasion during the last six months (elevated ALT group). Percutaneous liver biopsy was performed in all patients. Formalin-fixed specimens were assessed by one pathologist, who was unaware of the clinical and biochemical details. Histological activity (grade) was scored from zero to 18, and fibrosis (stage) from zero to six using the modified histological activity index 5 .The study protocol was approved by the Hospital Ethics Committee, and all patients provided written informed consent. Data were analyzed using SPSS (V 10.0.1) software, and student t test, chi-squared test, and Mann-whitney test as appropriate.

\section{RESULTS}

Patient characteristics and frequency of risk factors for HCV infection were similar in the two groups (Table).

The table shows distribution of histological activity grade and fibrosis stage in patients with normal and elevated ALT. Median (range) histological activity grade in patients with elevated ALT (6 [1-15]) was higher than that in patients with normal ALT (5 [0-11]; $p<0.001)$, as was the fibrosis score (2 [0-6] versus ( 1 $[0-6] ; p<0.02)$ Among patients with elevated serum ALT, 4 (5.3\%) had histological evidence of liver cirrhosis, and 12 (15.8\%) had bridging fibrosis, as did two and one patients, respectively, with normal ALT.

\section{DISCUSSION}

Persistently normal ALT is usually defined as ALT levels in the normal range during a 6 -to-12 months period ${ }^{11,12}$. We defined persistently normal ALT as at least 3

\begin{tabular}{|c|c|c|}
\hline \multirow[t]{2}{*}{ Characteristics } & \multicolumn{2}{|c|}{ ALT level } \\
\hline & $\begin{array}{l}\text { Normal } \\
(n=40)\end{array}$ & $\begin{array}{c}\text { Elevated } \\
(n=76)\end{array}$ \\
\hline Serum ALT level (IU/L)* & $33(10-45)$ & $\begin{array}{c}85(50- \\
985)\end{array}$ \\
\hline Age (y) & $42(18-67)$ & $41(19-64)$ \\
\hline Gender (M:F) & $35: 5$ & $63: 13$ \\
\hline Body mass index & $\begin{array}{c}23 \\
(17.8-27.8)\end{array}$ & $\begin{array}{c}22(16.6- \\
31.0)\end{array}$ \\
\hline Smoker & $21(53 \%)$ & $40(53 \%)$ \\
\hline $\begin{array}{l}\text { Risk factor } \\
\text { Intravenous drugs abuse } \\
\text { Blood transfusion } \\
\text { Surgery } \\
\text { Prior dental surgery }\end{array}$ & $\begin{array}{c}9(23 \%) \\
5(13 \%) \\
3(8 \%) \\
8(20 \%)\end{array}$ & $\begin{array}{c}28(37 \%) \\
10(13 \%) \\
4(5 \%) \\
13(17 \%)\end{array}$ \\
\hline $\begin{array}{l}\text { Histological activity grade* } \\
0 \\
1-3 \\
4-6 \\
7-9 \\
10-12 \\
13-15 \\
16-18\end{array}$ & $\begin{array}{c}2 \\
12 \\
17 \\
8 \\
1 \\
- \\
-\end{array}$ & $\begin{array}{c}- \\
11 \\
28 \\
23 \\
12 \\
2\end{array}$ \\
\hline $\begin{array}{l}\text { Stage of liver fibrosis* } \\
0 \\
1 \\
2 \\
3 \\
4 \\
5 \\
6\end{array}$ & $\begin{array}{c}5 \\
16 \\
9 \\
6 \\
1 \\
1 \\
2\end{array}$ & $\begin{array}{c}5 \\
21 \\
19 \\
9 \\
6 \\
12 \\
4\end{array}$ \\
\hline
\end{tabular}

Table-Characteristics of patients with HCV infection and normal or elevated ALT levels

Date are shown as median (range) or as number (\%); ${ }^{*} p<0.05$

consecutive serum levels below the upper limit of normal. Using this definition, we found that stage and grade of liver disease was lower among patients with persistently normal serum ALT. Nutt et al, found that mean (SD) HAI scores were 4 (2) among patients with normal serum ALT levels and 7 (3) among patients 
with elevated levels ${ }^{12}$. Corresponding figures were 2.96 (1.62) and 5.39 (2.81) in another case-control study $^{13}$. Our findings are similar to those in previous studies, which found that patients with normal ALT values had milder liver damage than those with abnormal ALT values ${ }^{14,15,16}$.

In our study, $5 \%$ of patients with normal ALT level had cirrhosis and $3 \%$ percent had bridging fibrosis. In the study by Nutt et al, ${ }^{12}$ these figures were $11 \%$ and $9 \%$, respectively. However, in another study of patients with normal serum ALT, none had cirrhosis and only $3.1 \%$ had bridging fibrosis. In another study, only $4 \%$ of patients with persistently normal ALT had chronic hepatitis and only $1 \%$ had cirrhosis ${ }^{15}$. Mathurin et $\mathrm{al}^{17}$ showed that in HCV RNA-positive patients with normal ALT values, the progression to fibrosis was slower than that in patients with elevated ALT. There is disagreement on whether HCV-infected persons with normal ALT values warrant treatment ${ }^{18,19}$. In the study by Nutt et al, $46 \%$ of patients with normal serum ALT levels had histological activity index more than 5, compared to $86 \%$ of patients with elevated ALT levels. Our findings were similar to these in that normal serum ALT levels do not exclude histological findings that might constitute an indication for antiviral therapy.

Thus, regardless of the serum ALT level, the decision to initiate therapy should be based on the severity of liver disease on histology ${ }^{6}$.

In conclusion, though persistently normal ALT levels among patients with chronic hepatitis $\mathrm{C}$ are associated with milder histological activity and fibrosis, these do not exclude presence of advanced liver disease.

\section{Copyright@ 05 Sep, 2012.}

\section{REFERENCES}

1. V Lo Re, Kostman JR. Management of chronic Hepatitis C. Postgrad Med J 2005; 81: 376-82.

2. Ray K W. Global epidemiology and burden of Hepatitis C. Microbes Infect 2004; 4: 1219-25.
3. Higuchi M, Tanaka E, Kiyosawa K. Epidemiology and clinical aspects on Hepatitis C. Jpn J Infect Dis 2002; 55: 69-77.

4. Hamid S, Umer M, Alam A, Siddiqui A, Quraishi H, Butt J. PSG consensus statement on management of Hepatitis C virus infection. J Pak Med Assoc 2004; 54 : 146-50.

5. Pradat P, Alberti A, Poynard T, Esteban JI, Weiland 0, Marcellin $P$, et al. Predictive value of ALT levels for histologic findings in chronic hepatitis C: a European collaborative study. Hepatology 2002;36:973-7.

6. Strader DB, Wright T, Thomas DL, Seeff LB. Diagnosis, management, and treatment of hepatitis $C$. Hepatology 2004;39:1147-71.

7. Parti D, Taioli E, Zanella A, Della Torre E, Butelli S, Del Vecchio $E$, et al. Updated definitions of health ranges for serum alanine aminotransferase levels. Ann Intern Med 2002;137:1-10.

8. Ishak K, Baptista A, Bianchi L, Callea F, De Groote J, Gudat $F$, et al. Histologic grading and staging of chronic hepatitis. J Hepatol 1995;22:696-9.

9. Sood A, Vandana M, Neena S, Harpreet K, Malhotra V, Awasthi G. Chronic hepatitis C in Northern India. The pathological and clinical spectrum. JAPI 2004; 52: 380-4.

10. Sadik M, Akber M, Hanif G, Noman K. Liver biopsy in patients infected with chronic hepatitis $c$ and persistently normal serum ALT levels. J Liaquat Uni Med Health Sci 2008; 7: 87-92.

11. Bravo A, Sheth S, Chpora S. Liver biopsy. N Engl J Med 2001;344:495-500.

12. Nutt AK, Hassan HA, Lindsey J, Lamps LW, Raufman JP. Liver biopsy in the evaluation of patients with chronic hepatitis C who have repeatedly normal or nearnormal serum alanine aminotransferase levels. Am J Med 2000;109:62-4.

13. Ohkoshi S, Tawaraya H, Kuwana K, Harada T, Watanabe $\mathrm{M}$, Higuchi S, et al. A retrospective study of hepatitis C virus carriers in a local endemic town in Japan. Dig Dis Sci 1995;40:465-71.

14. Pasquale G, Sagnelli E, Coppola N, Scarano F, 
Scolastico C, Bellomo PF, et al. Is liver biopsy necessary for hepatitis C virus carriers with persistently normal aminotrasnferase levels? Eur J Gastroenterol Hepatol 2003;15:831-3.

15. Herve S, Savoye G, Riachi G, Hellot MF, Goria 0, Lerebours E, et al. Chronic hepatitis C with normal or abnormal aminotransferase levels: is it the same entity? Eur J Gastroenterol Hepatol 2001;13:495-500.

16. Puoti C, Castellacci R, Montagnese F, Zaltron S, Stornaiuolo G, Bergami N, et al. Histological and virological features and follow-up of hepatitis $C$ virus carriers with normal aminotransferase levels: the Italian prospective study of the asymptomatic C carriers (ISACC). J Hepatol 2002;37:117-23.
17. Mathurin $\mathrm{P}$, Moussalli J, cadranel JF, Thibault V, Charlotte F, Dumouchel $P$, et al. Slow progression rate of fibrosis in hepatitis C virus patients with persistently normal alanine transaminase activity. Hepatology 1998;27:868-72.

18. Gholson CF, Morgan K, Catinis G, Favrot D, Taylor B, Gonzalez E, Balart L. Chronic hepatitis C with normal aminotrasferase levels: a clinical histologic study. Am J Gastroenterol 1997;92:1788-92.

19. Martinot-Peignoux M, Boyer N, Cazals-Hatem D, Pham BN, Gervais A, Le Breton V, S, et al. Prospective study on anti-hepatitis C virus positive patients with persistently normal serum alanine transaminase. J Pediatr Gastroenterol Nutr 2002;34:52-8.

\section{AUTHOR(S):}

1. DR. JAVED AHMED PHULPOTO, FCPS

Assistant Professor of Medicine, Ghulam Mohammad Mahar Medical College (GMC) \& Hospital, Sukkur

\author{
Correspondence Address: \\ Dr. Javed Ahmed Phulpoto \\ Assistant Professor of Medicine, \\ Ghulam Mohammad Mahar Medical College (GMC) \& \\ Hospital, Sukkur \\ jphulpoto@yahoo.com
}

Article received on: 23/02/2012 Accepted for Publication: 05/09/2012 Received after proof reading: 10/12/2012

\section{PREVIOUS RELATED STUDIES}

Dilshad Muhammad, Khalid Amin, Amin Anjum, Masood Javed. CHRONIC HEPATITIS C VIRUS INFECTION; ASSOCIATION WITH TYPE 2 DIABETES MELLITUS (Original) Prof Med Jour 17(4) 557-562 Oct, Nov, Dec 2010.

Fatima Mehboob, Zafar Majeed Babar, HEPATITIS C PATIENTS; TREATMENT COMPLIANCE OF HAVING POOR SOCIO-ECONOMIC BACK GROUND (Original) Prof Med Jour 15(1)61 - 66 Jan, Feb, Mar, 2008.

Faqir Muhammad Tariq, Habib Subhani, Irshad Ahmad, Irshad ul Haq. HEPATITIS C; PREVALENCE IN PARAMEDICAL STAFF OF A TEACHING HOSPITAL(Original) Prof Med Jour 16(2) 168-172Apr, May, Jun, 2009.

Muhammad Afzal, Irfan Ahmed Mughal, Naushen Afzal, Muhammad Badar Bashir, Fiyaz Ahmed Malik. CHRONIC HEPATITIS C INFECTION; CORRELATION OF GLUCOSE TOLERANCE TEST, THE LEVELS OF FASTING BLOOD SUGAR (FBS) AND HEMOGLOBIN (Original) Prof Med Jour 11(2) 222-227 Apr, May, Jun, 2004.

Muhammad Naeem, Ameer Ahmad, Imran Qaisar, Fiaz Ahmad. STATUS OF HEPATITIS C VIRUS (HCV) INFECTIONS; CHILDREN ADMITTED IN PEDIATRIC WARD OF BAHAWAL VICTORIA HOSPITAL BAHAWALPUR (Original) Prof Med Jour 18(3) 445-449 Jul, Aug, Sep 2011.

S. M. Abbas Naqvi, Qurban ali Khaskheli, Shahid Habib Ansari, Muhammad Shiraz Khan, Muhammad Saeed Talpur. HEPATITIS C VIRUS; PREVALENCE IN BLOOD DONORS IN KARACHI (Original) Prof Med Jour 13(4)604-607 Oct, Nov, Dec, 2006.

Sajjad Iqbal, Rashid Ahmed, Muhammad haroon Yousaf, Asim Mumtaz, Dawood Amin, Ghulam Rasool, Azmat Manzoor. HCV INFECTED PATIENTS; ASSESMENT OF MAJOR GENOTYPES AND SUBTYPES OF HEPATITIS C VIRUS (Original) Prof Med Jour 14(2) 266-271 Apr, May, Jun, 2007. 